\title{
Rural Education and teaching material: an analysis of History textbooks ${ }^{\mathrm{i}}$
}

Cícero da Silva ${ }^{1 i i}$, Ilário Dias Cardoso Filho ${ }^{2}$

${ }^{1}$ Universidade Federal do Tocantins - UFT. Departamento de Educação do Campo. Avenida Nossa Senhora de Fátima, 1588. Céu Azul. Tocantinópolis-TO. Brasil. cicolinas@yahoo.com.br. ${ }^{2}$ Universidade Federal do Tocantins - UFT.

\begin{abstract}
In this paper, the aim is to analyse history textbooks (LDH) used by Elementary School (6th grade) in rural schools located in the municipality of Tocantinópolis-TO. Considering that the training in the Rural Education perspective has made it possible to recognize and value knowledge and culture, seeking the emancipation of the peasants, this investigation of the selected teaching material includes an analysis of the following elements of the textbooks: (1) contents; (2) activities; (3) teacher-student interaction; and (4) images. The research is of bibliographic nature and qualitative approach. The corpus consists of two LDHs: one produced for the Programa Escola Ativa and another for schools located in urban areas, but also used in the rural schools of research context. In view of the reality of rural schools and the social, political and economic context in which the peasants have lived, the research results have revealed that only one of the LDHs analyzed follows the principles defended by Rural Education.
\end{abstract}

Keywords: Textbook, History, Rural Education. 


\section{Educação do Campo e material didático: uma análise de livros didáticos de História}

RESUMO. Neste artigo, o objetivo é analisar Livros Didáticos de História (LDH) utilizados no Ensino Fundamental ( $6^{\circ}$ ano) em escolas do campo situadas no município de TocantinópolisTO. Considerando que a formação na perspectiva da Educação do Campo possibilita reconhecer e valorizar os saberes e a cultura, buscando a emancipação dos camponeses, o estudo do material didático selecionado compreende uma análise dos seguintes elementos das obras: (1) conteúdos; (2) atividades; (3) interação professor-aluno; e as (4) imagens. A pesquisa é de natureza bibliográfica, de abordagem qualitativa. O corpus é constituído por dois LDH: um produzido para o Programa Escola Ativa e, outro, destinado às escolas situadas no meio urbano, mas adotado também por escolas do campo do contexto da pesquisa. Tendo em vista a realidade das escolas do campo e do contexto social, político e econômico em que vivem os camponeses, o estudo revelou que apenas um dos LDH analisados atende aos princípios defendidos pela Educação do Campo.

Palavras-chave: Livro Didático, História, Educação do Campo. 


\section{Educación Rural y material didáctico: un análisis de libros didácticos de Historia}

RESUMEN: En este artículo, el objetivo es analizar Libros Didácticos de Historia (LDH) utilizados en la Enseñanza Fundamental $\left(6^{\circ}\right.$ año $)$ en escuelas rurales situadas en el municipio de Tocantinópolis-TO. Considerando que la formación en la perspectiva de la Educación Rural posibilita reconocer y valorar los saberes y la cultura, buscando la emancipación de los campesinos, el estudio de material didáctico seleccionado comprende un análisis de los siguientes elementos de las obras: (1) contenido; (2) actividades; (3) interacción maestro-alumno; y las (4) imágenes. La investigación es de naturaleza bibliográfica, de abordaje cualitativo. El corpus está constituido por dos LDH: uno producido para el Programa Escola Ativa y, otro, destinado a las escuelas situadas en el medio urbano, pero adoptado en escuelas rurales del contexto de la investigación. En vista de la realidad de las escuelas rurales y del contexto social, político y económico en que viven los campesinos, el estudio reveló que sólo uno de los LDH analizados atiende a los principios defendidos por la Educación Rural.

Palabras clave: Libro Didáctico, Historia, Educación Rural. 


\section{Introduction}

The struggle and resistance of social movements that represent the peasants against the oppression and the denial of rights - have generated effects. The "Conferences by a Basic Education of the countryside", carried out in the country since the first that happened in 1998, in the city of Luziânia-GO, signal in this direction. From it and, under strong pressure from the rural social movements, the Brazilian Government has established actions aiming to support technically and financially the States, Municipalities and the Federal District on the execution of public policy of Rural Education to meet the demands of the people of the countryside, although the current management is dramatically reducing the resources allocated to this public policy.

To promote this specific educational policy in order to meet the demands (in Elementary School) of the peasants, the Federal Government implemented some programs, such as: Programa Escola Ativa (1997), Programa Nacional de Educação na Reforma Agrária - PRONERA (1998), Projovem Campo - Saberes da Terra (2009), just to name a few. In addition, programs were also created aimed to the training of teachers of the Rural Education, as well as the distribution of some teaching materials (MD) specific to attend schools in the countryside. Obviously, this set of actions aims to increase access and the qualification of the offering of basic education and higher education to the people of the countryside. However, we support the premise that the success of the training in the perspective of Rural Education also depends on the MD elaborated based on the reality of the context of the countryside.

Thus, the aim of this study iii is to analyze history textbooks used in the sixth grade of the Elementary School of the Rural Education in rural schools and in training program for peasants in the municipality of Tocantinópolis-TO, microregion of the Bico do Papagaio. It is, therefore, of a bibliographical nature and of qualitative approach. The corpus consists of two different copies of History Textbooks (LDH) selected for analysis, namely: Caderno de Ensino Aprendizagem: História 5-LDH 1 (of the Programa Escola Ativa) and Vontade de Saber História - LDH 2, of the sixth year (produced for schools situated in the urban environment, but also adopted by schools in the countryside of Tocantinópolis-TO).

Based on theoretical-methodological approach taken in the research, in the analysis of this teaching material of the sixth grade of Elementary School we focus 
on constituent aspects of both works, such as: (1) contents; (2) activities; (3) teacherstudent interaction; and (4) images, whose intention is to understand differences/particularities among the contents submitted by LDH analyzed in relation to purposes of Rural Education.

The work is organized in two parts. The first, in addition to this Introduction, brings a synthesis of research carried out about the Textbook (LD) of the Rural Education, including the production and distribution of LD by the Ministry of Education (MEC). The second part presents methodological aspects of the research, characterization of the works analyzed, as well as the discussion of the research data. In the end, we present some considerations regarding the study.

\section{The Textbook (LD) in the Rural Education}

The Textbook (LD) consists of a multitude of knowledge gathered and selected, conditioned by social theories, beliefs, values and ideological intentionality in a limited amount of sheets of paper (see Arboit \& Pacheco, 2013). Generally, it is divided by area of knowledge (History, Geography, Mathematics, Biology, Languages) and functions as a guide to lead the teaching- learning process of teachers and students, with the contents that includes.

Whereas our research object is the History LD of the Elementary School, we will not treat about books from other disciplines in this article. Research regarding the production, circulation and uses of History teaching materials $\left(\mathrm{MD}^{\mathrm{iv}}\right)$ of Elementary School, above all in the Rural Schools, still present a reduced number. We highlight here the works of Arboit and Pacheco (2013), Costa (2014) and Berbat and Feijó (2016).

The study of Arboit and Pacheco (2013, p. 140) aims to "... know how the life and work daily of the countryside is depicted by the schoolbooks used in rural and urban schools". According to the authors, the results of the research showed that the LD spreads stereotypes which favor the perpetuation of a dichotomized vision, conveying beliefs that overvalued the urban, as natural environment, and unique of development, economic success and progress. The rural context in the LD is minimized, highlighting difficulties, suffered life, hard work and low remuneration. According to the authors, it urges to resign educational public policies in order to establish in the LD "... a policy of valuing of the diversity, able to point new paradigms, which appear on the horizon as proposal of overcoming of the 
social inequalities, impregnated in this capitalist system, aiming to promote social inclusion" (Arboit \& Pacheco, 2013, p. 151).

On the other hand, the research of Costa (2014, p. 10) has as object of study the LD of the 5th year of the Elementary School of the Foundation of the Programa Escola Ativa, whose aim is to "identify the discursive strategies turned to the contextualization of these books prepared specifically for the Rural Education evaluating the assumptions leaders of the choices that characterize them as included in a specific reality". In the analysis, the author uses two LD of the fifth grade of Elementary School of Escola Ativa, being one copy of Portuguese Language and one History.

Differently of what revealed the study of Arboit and Pacheco (2013), the findings of the investigation of Costa (2014) showed that there is an attempt in the works analyzed privilege experiences of peasant students, as well as adding to them new visions regarding the context of the countryside and bring themes linked to struggles of social movements by land and the Agrarian Reform, to the struggle in favor of the polyculture in contrast to monoculture, to the protection of the collective work done by the family in the community and its participation in school, as well as the need to specific public policies turned to meet the demands of the countryside.

Berbat and Feijó (2016) also developed a research on MD, whose purpose is to identify the whether the relevance or not of the LD from the countryside regarding the educational reality of a rural school of municipal public education network situated in a municipality in the State of Rio de Janeiro. The research takes into account the cultural and social space lived by the students. The data of this research include LD used by students, interviews with a teacher and students of the countryside school.

According to Berbat and Feijó (2016), the results of the study revealed that, although the National Textbook Program of the Countryside (PNLD Countryside) has the goal to distribute works that contemplate the specificities of the field, having in view the reality of the context "some works do not consider the multigraded organization, nor are related so pertinently to the peasant context in his fights, forms of reproduction of the existence, identity and culture" (Berbat \& Feijó, 2016, p. 476). So, they are observations that concern and need to be solved.

In relation to the public policy turned to the MD, the Federal Government 
instituted, at different times of the trajectory of the Brazilian education, committees and programs linked to the Ministry of Education (MEC) with the assignment of facilitate the evaluation, purchase and distribution of LD for the basic education all around the country (see Freitas \& Rodrigues, 2008; Filgueiras, 2013). Although recent, the enhance of the National Textbook Program of the Countryside (PNLD Countryside), which makes the distribution of LD (including History) for schools located in the countryside. This program has as its main aim:

... to consider the specificities of the social, economic, cultural, political, environmental, of gender, generational, of race and ethnicity of the Countryside People, as reference for the elaboration of textbooks for the early years of elementary school (graded and not graded), of countryside schools, of the public education networks (Brasil, 2012, p. 9).

It is about a public policy of fundamental importance, since it can promote the production of LD to include the specifics the rural context, although the search of Berbat and Feijó (2016) has revealed in its analyses, inadequacies in the LD of the PNLD Countryside.

Besides the PNLD Countryside, in recent years the MEC programs turned to the Rural Education also produce and distribute some teaching materials (LD, classnotes, among others) for the schools in the countryside. The general coordination of the Rural Education, for example, in partnership with the Secretariat of Continuing Education, Literacy and Diversity (SECAD) and the MEC elaborated the LD of the Programa Escola Ativa ${ }^{v}$ for the initial series of the Elementary School, of the education in the countryside. These LD are part of the compilation Cadernos de Ensino Aprendizagem, which brings specific volumes of: History, Geography, Portuguese Language, Mathematics, Sciences and Literacy (see Brasil, 2010). The LD of the Escola Ativa had its first edition published in the year 2010, with pedagogic themes and theoreticalmethodological guidelines turned to the work in multigraded classes. Therefore, one of the History LDs analyzed in this research is part of that referred collection.

\section{Research Methodology}

The research of qualitative approach (Bogdan \& Biklen, 1994) and interpretative analysis of data, it is characterized as bibliographic. We understand that the bibliographic review allows you to present conceptual 
framework settings, giving support to the woven analyses regarding the selected data in the study. In addition, in the qualitative investigative approach “... everything has potential to build a clue that enables us to establish a more insightful understanding of our object of study" (Bogdan \& Biklen, 1994, p. 49).

The corpus of the research consists of two different copies of History Textbooks (LDH) used in the sixth grade of the Elementary School of Rural Education in countryside schools and training programs of peasants in the municipality of Tocantinópolis-TO, microregion of the Bico do Papagaio, namely: Caderno de Ensino Aprendizagem: História 5-LDH 1 (of the Programa Escola Ativa) and Vontade de Saber História - LDH 2 (produced for schools situated in the urban environment, but adopted also by the rural schools from Tocantinópolis-TO).

Although there are other elements that deserve attention in researches about LD, the study of teaching materials (MD) chosen involves the analysis of the following elements of both works: (1) contents; (2) activities; (3) teacher-student interaction; and (4) images, whose intention is to understand differences/particularities among the contents presented by the LDH analyzed in relation to the purposes of the Rural Education.

\section{Teaching material (MD) chosen for the research}

In view of the formative proposal of Rural Education, the importance of History teaching and the MD used in the Programa Escola Ativa in the context of the research, the LDH 1 chosen for analysis is the Caderno de ensino e aprendizagem Historia 5, of the sixth grade of the Elementary School, published in 2010 by the MEC/SECAD (Silva, 2010). The author of this work is Lulia Queiroz Silva, the same who writes the other books of the area of History for the initial grades of the Elementary School of the Programa Escola Ativa.

The Cadernos de Ensino e Aprendizagem of the Escola Ativa, used by educators of the Rural Education, of History field, make up a series of 05 (five) volumes. According to the guidelines of the referred program, the collection has been developed to help the student to develop its activities in the classroom and in the community, favoring also the development of its autonomy (Brasil, 2010).

As regards the choice of the second book of History adopted in schools located in the countryside, in the municipality of 
Tocantinópolis-TO, was also selected one LDH of 6th grade of Elementary School. However, the LDH 2 was not produced exclusively for the schools in the countryside, in addition to not integrate the textbook Guide: PNLD Countryside 2013 (see Brasil, 2012). Nevertheless, this book is used by teachers who lecture in schools situated in rural area of the referred municipality.

The LDH 2 chosen for analysis is part of the collection Vontade de Saber História, which consists of four volumes (from the 6th to the 9th year of Elementary School). This LDH is by authorship of Marco César Pellegrini, Adriana Machado Dias and Keila Grinberg and was published by the Editora FTD in 2012. This is a work that integrates the National Textbook Program (PNLD) of 2014. It was evaluated and chosen by teachers from various schools in the public school system from all around Brazil, to be worked in the years of 2014, 2015 and 2016 (Brasil, 2013).

During the collection of the MD for the research, we verified that the LDH 2 is used by children of the 6th grade of the Elementary public Schools of the urban educational network and some schools located in rural areas of the municipality of Tocantinópolis-TO, although it was not produced in attention to the Rural
Education guidelines. These schools from the public education system received this LDH through the PNLD, whose distribution is made by the MEC, through the National Fund for the Education Development (FNDE).

\section{Discussion and data analysis}

Following a common feature of the MDs, in both LDHs the authors do - in the space reserved the presentation - a preview of the contents and leave a message about the importance of the study of history. The LDH 1, Caderno de Ensino Aprendizagem: História 5, there is a message of rapprochement with the daily life of the child of the countryside, in which seeks to situate it in a universe of responsibility about the contents that will study. The LDH 2, Vontade de Saber História - 6th year, the authors also comment about the purpose of the study of history, to show respect to the cultural diversity, as the basis for the exercise of citizenship and the construction of a better world.

The LDH 1 Caderno de Ensino Aprendizagem: História 5 - 6th grade - is organized into four units, divided into sixteen chapters (see Silva, 2010). In each unit, the author presents an "Introduction" of the issues that will be studied and a proposed activity to be developed by 
children. The chapters always start with questions about the topics that will be discussed by the students, introducing then a brief introduction of the text-based content, with a sequence of exercises, panel mounting or documentaries. At the end of the completion of the units, the author congratulates the students and calls for it to be performed at a school one event on the subject that was studied in the chapter. This event is called "Day of the conquest", in which the students present the works (developed) to other peers and educators from school or invite someone from the community to tell experiences on the subject. The end of the book is composed of a Caderno de Avaliação, with an objective and discursive questionnaire related to each one of the units studied.

On the other hand, the LHD 2, Vontade de Saber História - 6th year is organized into twelve chapters (see Pellegrini, Days \& Grinberg, 2012). The chapters always start with two or more images (photography, painting, drawing) on the main theme to be studied, followed by the section "Talking about the subject", which consists of a small questionnaire. After this introduction, the authors develop the contents, and, at the end of each chapter, is presented the section: "Exploring the theme", spaces related to curiosities, as well as the "activities". And, finally, in the subsection "reflecting on the chapter", students are invited to perform a self-evaluation of their learning.

\section{Contents of the LDH and relationship with the Rural School}

The Rural School presents an innovative formative proposal which, through a modality of education with specific grounds, has the purpose of forming conscious citizens. Because politically conscious citizens and aware of their rights, are able to, in collective Union, fighting to defend the ideals of the countryside and of the peasants. The school recommended by the peasants values its experiences and knowledgegenerating as elements of organization of its pedagogical structure and its curriculum.

Thus, the struggle for the construction of the Rural School, appreciation of culture, knowledge and identity of the peasants, must pass through the selection of the contents (Arroyo, 2013), because the theories present in the contents are not neutral. They have a political purpose, that can be linked to a project that masks the social injustices produced by the capitalism, especially in the countryside, showing us the necessity of struggling against the oppression (Caldart, 2000). 
Considering both LDH selected for analysis and respective contents, Caderno de Ensino Aprendizagem: História 5 LDH 1 and Vontade de Saber História $\mathrm{LDH} 2$, the first book (LDH 1) brings contents turned to the understanding of the formation of the Brazilian society, starting with questions about: "How the human beings occupied the entire planet?", "Where did the first people of the Americas come from?", "How the human species came to Brazil?", until get to the period of the colonization. The book traces a historical route from the use, occupation and domination of the lands of Brazil, in its various aspects. Therefore, in the LDH 1 Silva (2010) seeks to demonstrate how every people has its relationship with the Earth, starting with the Indians, Portuguese and Africans, whereas these last ones were brought to Brazil as slaves.

In the chapters of the LDH 1 , the historical narratives about each subject studied are brief because in this volume it is explored intensively the use of exercises, group activities, activities with the family, whose purpose is to make the classroom a space reserved for debates, so that through shared experiences everyone (students and teacher) enrich their knowledge. How is a LD turned exclusively for the children of the countryside, Silva (2010) works instigating the deconstruction of some concepts that, of the historiographical point of view served to legitimize the political domination and the control of the lands by the Portuguese people, as "the discovery of Brazil".

To demonstrate the difference between the concepts, such as, for example, folwark and smallholdings, dating back to the Portuguese colonization in Brazil at the time of the Capitanias Hereditárias, the LDH 1 shows the social contrasts of the agrarian conflicts in the country. With this, the child may realize the political sense of the struggle of its parents in the settlement and in the social movement. However, it is important to note that the discussion and the deepening of these matters depend on the way the teacher will approach them with his students.

Unlike of what Arboit and Pacheco (2013) found in their search, it is important to note that, at no time in the $\mathrm{LDH} 1$ Caderno de Ensino Aprendizagem: História 5 the countryside is presented as a place of but as a place of backwardness, but as a place marked by a rich cultural diversity, due to the presence of the Indians, river people, sharecroppers, quilombolas, fishermen, among others.

On the other hand, the LDH 2 following the dominant trend in $\mathrm{LD}$ - deals with contents focused on the study of the 
classical history, spreading knowledge and discoveries of the Western and Eastern cultures. The book begins with the study about "The origin of human beings", how did the evolution of humans happened over the Paleolithic and Neolithic periods, i.e. the cultural development that starts with full contact of man with nature. The work also presents some findings, as the fire and the invention of the writing, and with the population growth on the planet Earth the life will become more complex, arising the first villages, and then cities. In fact, this story describes that, with the passage of the time, the man tends to deny the nature/countryside where it came from.

In both the LDHs (1 and 2), the authors discuss the evolution of man. They portray the possible hypotheses that describe how the man held or reached the Americas. They still talk about Bering's route Hypothesis, Coastal Route Hypothesis, Transpacific route Hypothesis and Atlantic Migration Hypothesis. These scenarios are described in the LDH 1, for example, showing how, did the domination of the Americas happen.

In turn, in the course of the chapters of the LDH 2 this work focuses on other people, showing the historical and cultural transformations of the following companies: "The peoples of Mesopotamia", "Ancient Greeks", “The ancient Romans", "The ancient Chinese", among others (Pellegrini, Days \& Grinberg, 2012). The chapters of the LDH 2 are organized by contents whose historical narrative deepens enough each theme approached, being accompanied by many concepts, glossary located at the margin of the text and several images. The narratives gravitate around social aspects, political, economic, cultural and religious societies studied. Somehow, that allows the student to accumulate knowledge whose purpose is the preparation for the labor market, and not a content-based formation thought for the reality peasant.

In the LDH 2, when there are references to the countryside and to the peasant culture, they appear in connection with the Egyptian, Greek, Phoenician and Chinese societies. Therefore, very far from the political, social and cultural contexts, of the peasant communities in Brazil, marked primarily by agrarian conflicts. One of the few possibilities of contextualization of the content with the reality of Brazil appears in the section reserved for the exercises, in which are stated some questions about Brazilian politics, culture, religion and music.

\section{The activities of the $\mathrm{LDH}$}


The LDH 1 Caderno de Ensino Aprendizagem: História 5 systematizes, for students and teachers, how the activities should be developed during class. Throughout the work, there are icons that make reference to the way each activity must be carried out. Altogether, six different types of activity are proposed, such as: "Individual activity", "Activities in couples", "Activities in small groups", "Collective Activity", "home Activity" and "reading" (Silva, 2010, p. 6).

The "Home activity", for example, enhances the importance of the Alternation Pedagogy (PA), which in the formative course the child spends some time at school and another time with its family, in the community, sharing the knowledge learned at school (see Silva, 2011). The "Collective Activity" demonstrates for the child the feeling of participation, that the knowledge is expanded when shared in group in the exchange of life experiences and knowledge. It directs us, to reinforce the conception of work and/or training in social movements, in the settlements and communities, the fight is collective. For this reason, the students are motivated to learn to work collectively.

The chapters of the LDH 1 always start with the section: "Collective Activity", which introduces the content with a block of questions, as seen in the example of Figure 1:

Figure 1 - Typology of activity questions - LDH 1 .
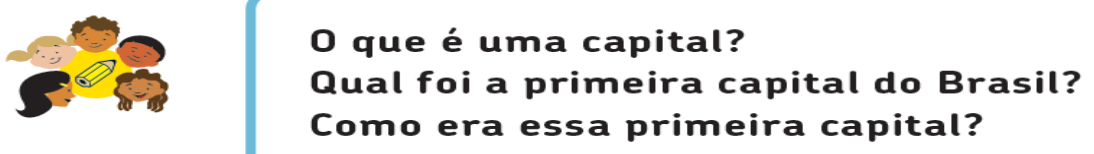

Source: Silva, 2010, p. 117.

In General, the questions are introduced by the pronoun who, what, why, how, what. In a way, require cognitive skills and whose solution can sometimes be found in the text, in addition to such questions motivate the socialization of responses among students (see Costa, 2014).
On the whole, the LDH 1 presents a $\operatorname{total}^{\mathrm{vi}}$ of 43 "Individual activities", 41 "Collective Activities", 83 "Activities in couples", 27 "Activities in small groups" and 05 "Home Activities". The methodological proposal of these activities involves: discussion in groups, reading of short texts, research accomplishment, 
questionnaires, analysis of charts, graphs, drawings and works of art that appear in the book. In relation to the "Home Activities", considered important by involving the participation of the family members, we realized that the book brings a reduced number.
Another relevant aspect of the LDH 1 is that it brings some activities that aim to portray the life and trajectory struggle of the people of the countryside, as shown in Figure 2:

Figure 2 - Systematization of activity - LDH 1.

\section{Recorte de revistas e jornais, ou faça desenhos, fotos mostrando como você vê, no seu entorno, o território do campesinato e o território do agronegócio.}

Source: Silva, 2010, p. 74.

This type of activity shown in Figure 2 includes the design of Rural Education proposed for Programa Escola Ativa, because

... is understood as a form of political and social action, as opposed to the traditional rural education, implementation impoverished of education constructed for urban areas. In the context of Rural Education, the school becomes recognized as a space for reflection of the reality of the people of the countryside, of its work, its languages, its ways of life and, above all, of a new political project of development (Brasil, 2010, p. 18).

Still in the LDH 1, content fixation exercises require skills and knowledge to solve them, consisting of recalling or recognizing information in the text or of a fact (Costa, 2014). Some issues require research in other books, magazines and newspapers, because the texts of the chapters of the work are summarized.

Analyzing other activities, we observe that this work also demonstrates, for example, how should be accomplished the analysis activity of the maps, which appear followed by an "Activity in small groups". That is, the images are not in the book only as illustration purpose; for example, after presenting two Brazil maps that show the distribution of indigenous peoples in the national territory: one of 1500 and another current, the book proposes the following activity on the maps: 
Figure 3 - Activity: analysis of Maps - LDH 1.

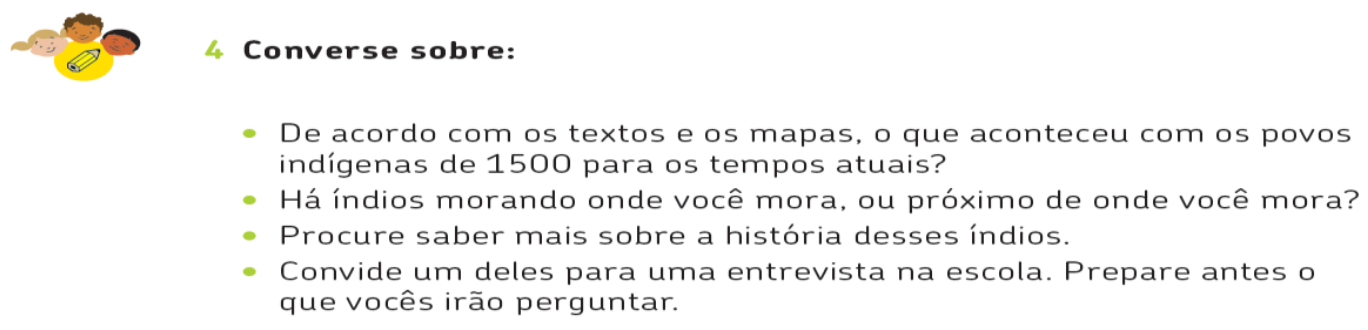

Source: Silva, 2010, p. 24.

According to Carie (2008, p. 30), this format of activity "proposes the debate and the exercise of skills involving the judgment and the criticism, the relationship between past and present, allowing students to position themselves on the themes studied". It seems also that the activities of map analysis bring a proposal of interdisciplinarity, because they relate, directly, with texts worked on Geography, especially with regard to the concept of territory.

As for the proposal or activity format present in the copy of the LDH 2 Vontade de Saber História, we verified that they appear divided into two sections. The first section - "Talking about the subject", begins with the introduction of the chapters in which are presented two or more images about the central theme to be studied. The images are followed by questions, being common the use of pronouns to introduce them: what, which, who or words as compare, describe, identify, whose purpose is to provoke reflection about the contrasts between past and the present.

In the section "Activities" of the LDH 2, are proposed various exercises compound of approximately 20 objective questions (each) about the content of the chapter. It seems that solve such activities means, in a way, to find in the text the information requested.

Figure 4 - Systematization of activities - LDH 2. 


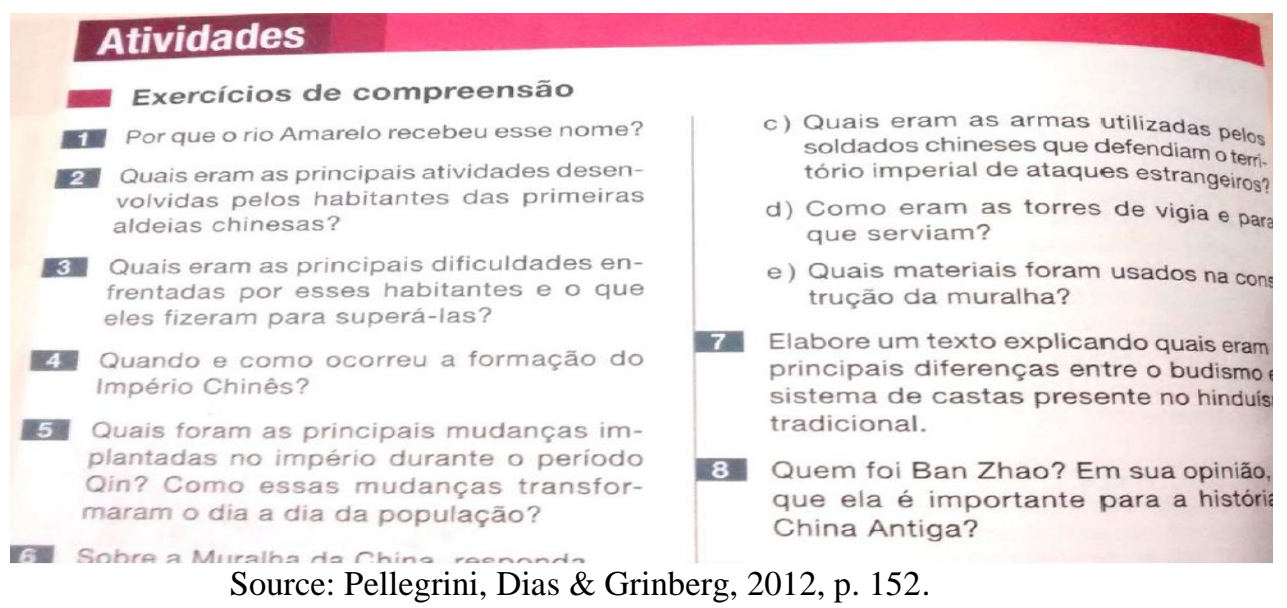

We must point out that the section "Activities" of that LDH is divided into five subsections: "Understanding Exercise", "Expanding the content", "In Brazil", "Discussing the Story" and "Reflecting about the chapter". The authors - in subsection "In Brazil" - in an attempt to bring closer the contents of the Brazilian reality, relate the subject studied with some fact of Brazil. For example, by studying the Greek democracy is requested that the students do a research to know how the Brazilian democracy works; in the study of Roman society and its struggle for territorial expansion, the connection is made by highlighting the importance of agrarian reform in Brazil. However, as highlights Costa (2014) in her search, the LD needs to present new approaches regarding the context of the countryside and bring themes linked to the struggles of social movements, such as the struggle for land and Agrarian Reform. Obviously, the struggle and access to the land cross over the democracy.

It is also noticed that in the section "Activities" of the LDH 2 there is not a clear proposal so that the same be carried out in groups, couple, collectively, not even home activities, although the PNLD's Guide recommends that "in the activities include individual and group works to aid in the learning of important concepts to the history" (Brasil, 2013, p. 131).

Finally, in the subsection of activity named "Reflecting about the chapter" the students are invited to perform a selfevaluation of its learning acquired about the chapter studied by checking if they could understand the contents. The figure (5) below demonstrates how are made the questions of evaluation of the learning at the end of each chapter:

\begin{tabular}{|l|l|l|l|l|l|l|l|}
\hline Rev. Bras. Educ. Camp. & Tocantinópolis & v. 3 & n. 1 & p. 76-103 & jan./abr. & 2018 & ISSN: 2525-4863 \\
\hline
\end{tabular} 
Figure 5 - Systematization of activity: reflecting on the chapter - LDH 2.

Refletindo sobre o capítulo
Agora que você finalizou o estudo deste capítulo, faça uma autoavaliação de seu apren-
dizado. Verifique se você compreende as afirmações a seguir.
= O continente africano apresenta, desde a Antiguidade, uma grande diversidade cultural.
" Na África Antiga havia tanto sociedades patriarcais como sociedades matriarcais.
" As candaces tiveram um papel importante na sociedade e na política africanas.
" Houve trocas de influências culturais entre os antigos povos africanos, como os egípcios
e os cuxitas.
Após refletir sobre essas afirmações, converse com os colegas e o professor para certifi-
car-se de que todos compreenderam o conteúdo trabalhado neste capítulo.

Source: Pellegrini, Dias \& Grinberg, 2012, p. 93.

According to the proposal illustrated in Figure 5, the information must be shared with classmates and teacher. Despite being a systematic activity to the "collective", we can point out that this book prioritizes little the knowledge construction of collective way in the interaction with the other, for example. Although the teacher is the actor responsible for leading the approach of the text and of the activities proposed in the LD in the classroom, and the contribution that this type of activity of the LDH 2 can provide to the peasants seems fairly limited considering the formative proposals of the Rural Education.

\section{Teacher-student interaction}

The interactions established between teacher-student in situations of teachinglearning in the classroom, and that involve the LD, this type of MD fulfills the role of mediator of this dialogue on basic education, because in it, it is hoped that be included the content/knowledge needed to be seized. On the other hand, the teacher acts as interpreter of the information present in the LD, since during the university and continuing education the teacher must have accumulated theoreticalmethodological knowledge sufficient to perform "transmission" of knowledge necessary for the training of students.

In the LDH 1 Caderno de Ensino Aprendizagem: História 5, the organizational structure of the contents and activities aims the debate and the reading in the classroom. Therefore, numerous activities are proposed in groups, collective and in the Community (see Silva, 2010). The role of the teacher is to mediate the discussions; to the students, is the responsible by following the guidance contained in this LD signalized by icons or words, as for example, when it is time to read it is presented the Tip: "Read". 
To answer certain activities, learners interpret and find some answers in the text, while others require broader reflection. Hence, it is responsibility of the teacher the task of stimulating the students to the development of responsibility and autonomy, in the search of answers to solve the problems.

The LDH1, considering the teacherstudent relationship, brings all the guidelines that indicate how to work at certain times the content, because the material is very interactive with figures, maps, drawings, comics, which contributes to facilitating the access to the information. Especially, regarding to the use of drawings of children; showing some information, as in a comic book, a question suggesting a search. This aspect of the work is shown in the image below:

Figure 6 - Teacher-student interaction - LDH 1.
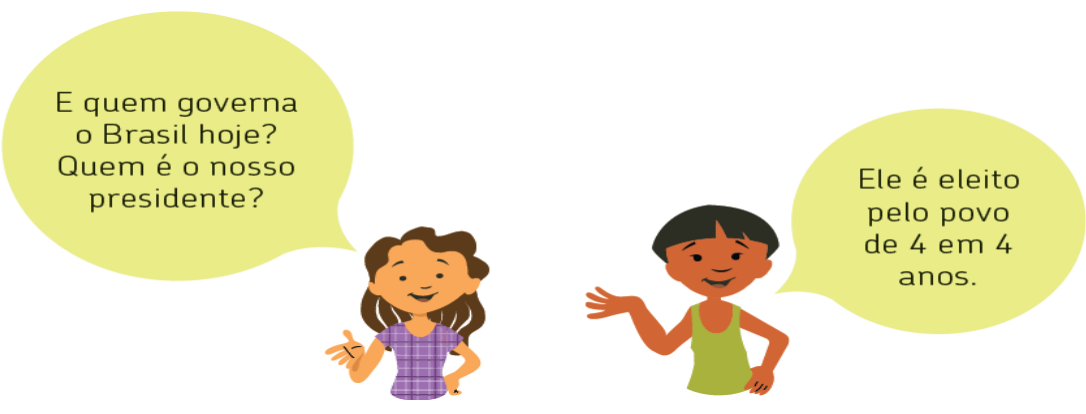

Source: Silva, 2010, p. 43.

The teaching-learning process in the LDH 1 is focused on the student, since this is handled along the work as active subject and constructor of knowledge. This student is what lives in the context of the countryside and shares with its families innumerous knowledge linked to the Earth, nature and peasant culture. The contents of the LDH 1 also bring an approach linked to the General History of Brazil. Based on the contents present in the work and depending on how these are developed in the classroom by the teacher, it is possible that the child understand the concepts linking them to the process of struggle for agrarian reform, the Rural Education, why the existence of so much land concentration currently in the country, for example.

The texts of the LDH 1 also have a language that is peculiar to that which we find in the social movements of the countryside. Silva (2010) employs words or phrases such as "occupation of the Brazilian territory', "struggle of the social groups", "valorization of the contribution of the cultures", "mobilization". This 
language is the language of the social movement, who speaks in a variety of ways, with the rituals and mystique, with children, with the symbols (Arroyo, 2011), since the words are not only symbolic characters, but carry with them a meaning of political and ideological world, liberator or oppressor. Furthermore, these words are related in the activities of an objective way to the context of the peasants, promoting the student-teacher interaction and pupilcountryside-social movement.

On the other hand, it seems that the teacher-student approach constant in the LDH 2 Vontade de Saber História is centered mainly in the figure of the teacher as keeper of knowledge. This can be determined based on how that LD is organized, beginning the content of the chapters with a general reflection, followed by several titles and subheads that bring a historical narrative (see Pellegrini, Days \& Grinberg, 2012) in which the teacher assumes the role of performing the analysis of contents and the concepts presented. But, in the PNDL guidelines,

The pedagogical proposal values the mediator teacher and approaches of the socio-interacionist proposal. It proposes to working with the reading and the interpretation of images favoring the construction of historical knowledge. In the activities, are included individual and work in groups to aid in the learning of concepts important to the story (Brasil, 2013, p. 131).

As the LDH 2 does not present a systematic path to be followed regarding the teaching of contents that gives autonomy to the teacher use the most appropriate methodology to its educational practice: individual reading, reading in couples, text annotations, text summary seminars.

In the analyses, it was also found that the activities of the LDH 2 follow the same trend, presenting a formal language in the text and the focus turns to the definition of many concepts that arise throughout the book. This makes the figure of the teacher central in the classroom, since students may find it difficult to understand the texts.

As the contents of the LDH 2 are extensive, in the reading of the texts, the students may lack certain previous knowledge for interpretation. Therefore, the teacher can use as teaching resource, the reading in group to facilitate the understanding, what enables to improve the teacher-student interaction.

\section{The images on the $\mathrm{LDH}$}

The use of images in the LD is justified also by the role that assume of "transport our imaginations" to a historical past, a current reality or a future time. 
They give visual and imagery grounding, enriching the cultural capability of the students and educators, besides of encouraging playful interaction with the contents.

In addition, to present images in MD is a form of legitimate historical speeches (Ströher, 2012), that is, they validate with visual evidences that is being said, even that is not part of the everyday reality of the learner. The images compound of pictures, cartoon/caricature, billboard, newspaper page, magazine, map and graphics, educate our way of thinking and perceiving the world around us, because the human mind is "formed" by words and pictures. So, we can read the world through both the words and the images, assigning meaning and concepts to the things that surround us. In this dialectical process, we transform the world and ourselves.

According to Ströher (2012), you can set three categories of analysis of how the images are used methodologically in the LD, namely:

Picture-illustration, with only decorative function, without direct relation to the accompanying texts or that are unnecessary for the understanding of the same;

Image-proof, presented as a portrait of the past, confirming or restating what the text argues, acting as confirmatory element of the speech of the author;

Image of monument, which discusses the source and questions it, but without taking it as the only truth of the past (Ströher, 2012, p. 51, bold in the original).

Following this criterion, we verified that the LDH 1 is a rich volume Iconographies. The purpose of them at the work seems to be to provide to the students more relaxed learning situations, showing them the "Little group of the countryside", that will accompany them throughout the course of the initial series. This little group is presented already in the first copy of the Coleção Cadernos de Ensino Aprendizagem História, volume 1. The name, Little group of the countryside, is a designation that reinforces the identity of the peasant culture in the social imaginary of the child at an early age can learn to value its people, its culture and the place where it is living. The figure below illustrates the actors who make up the little group of the countryside:

Figure 7 - Little group of the countryside - LDH 1. 


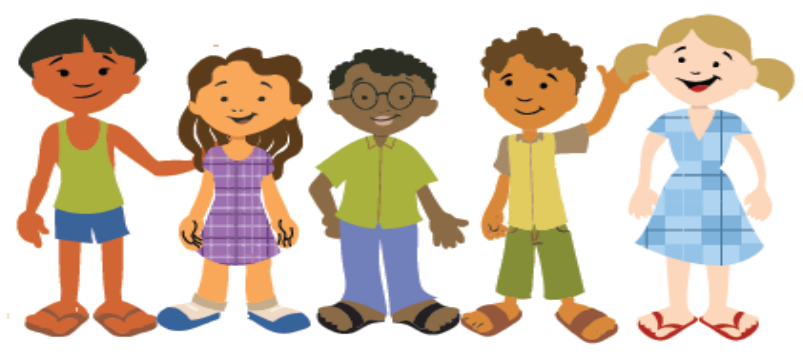

Source: Silva, 2010, p. 7.

As we verified in other parts of the LDH 1, the use of photographs, maps, graphics, paintings and cartoons (contemporary or not) also presents themselves as a resource to make reference directly or indirectly to the subject studied in each chapter. Because it is a volume whose theme is developed specifically for the students in the countryside, most of the images are used in order to develop a critical consciousness in children for the understanding, for example, of how happened the territorial domain of Brazil, the slavery, the development of the cities and the achievements of social rights.
However, some images present in the LDH 1 seem to be simply laid out on the work at the criterion of illustration (picture-illustration), making it unnecessary the presence of the same to the understanding of the texts. In some cases, is not made available for certain images the methodological feature appropriate to the interpretation of the same, that is, it is not proposed any activity that can involve the interaction in the classroom, such as is the case of the image (Figure 8) used when the subject of the text is the homo's sapiens (clever man, who knows, you can know):

Figure 8-Rupestrian paintings - LDH 1.
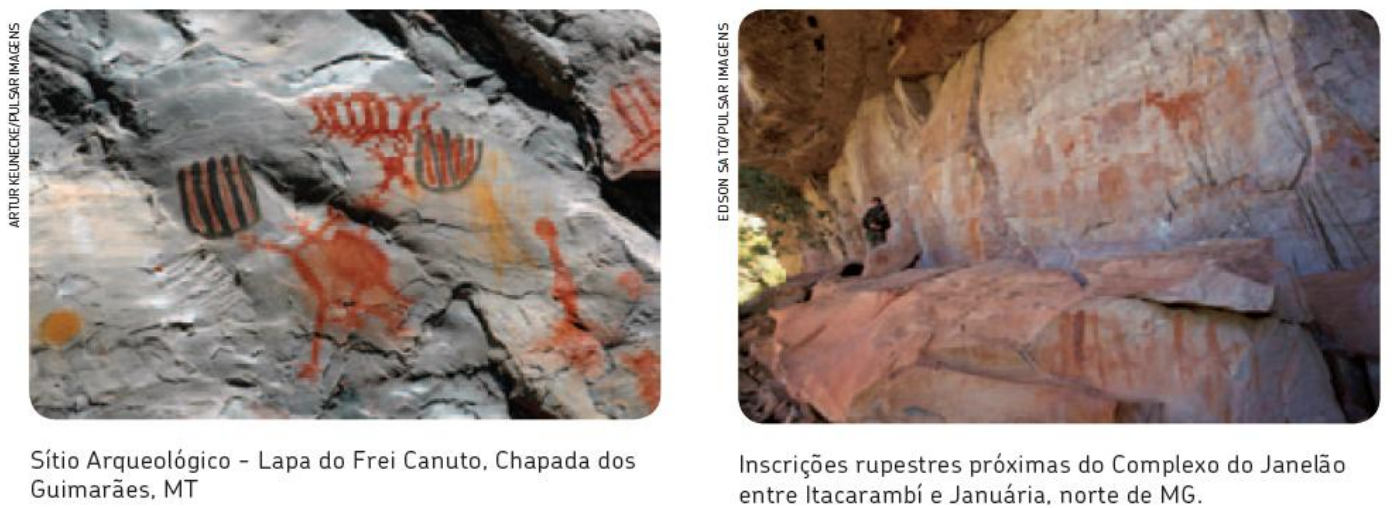

Source: Silva, 2010, p. 12.

Nevertheless, considering the overall the images of the LDH 1 present good scope of the work, we can say that most of reflective proposals, suggestions of 
individual or in couple activity, representation with sticking or drawing. For example, when the topic of study is the growth of the cities, are presented pictures preceded by a brief explanatory content about the development of Brazilian cities, framing within the criterion of image-proof (Ströher, 2012), which validates the narrative of the text. At the same time, it proposes an activity to analyze the images, very positive point of this LD.

It is important to point out that some images of the LDH 1, such as maps, photographs and paintings, do not have a detailed description about its theoretical approach, in order to facilitate the understanding of the content, although they are important to performance of the exercises. It can instill the kids to argue ("Talk about") the issues from what is shown; that is, taking into account the reality of the countryside, the teacher can help students deepen the discussion about a particular subject linked to the Brazilian countryside.

In the texts about territory, the LDH 1 also presents images that make it possible to take the students to understand that, in the countryside, there are different forms of occupation of the land. Figure 9, for example, brings the differences between the territories of the peasantry and agribusiness:

Figure 9 - Different territories - LDH 1.

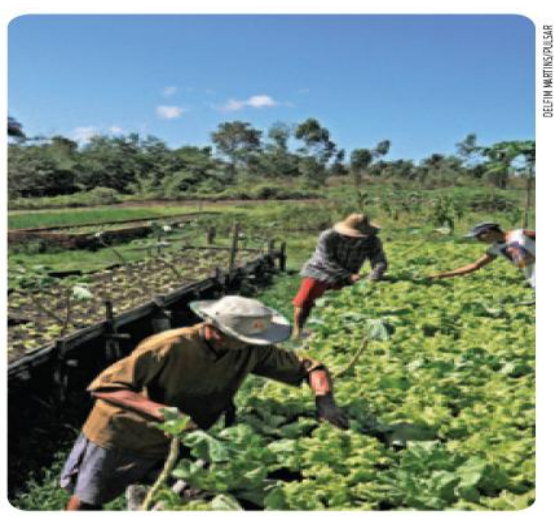

O território do campensinato com o sistema de
policultura e pequena criação

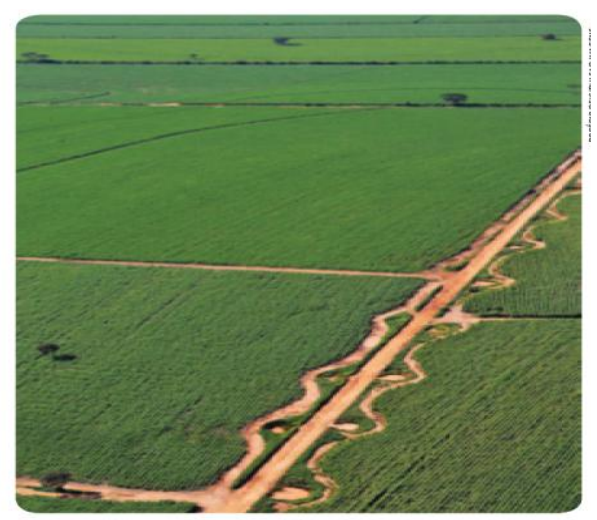

O território do agronegócio com todo seu poderio
econômico, a monocultura e os grandes criatórios.

Source: Silva, 2010, p. 74.

These images of the Figure 9 show that rural areas are taking varied social and cultural contexts of empowerment in accordance with the form of occupation by man. In this case, the teacher's role is vital, because it can explore in the readings and discussions with students: the story of the MST in the struggle for Agrarian Reform in the country, the importance of the family agriculture which employs more 
than the agribusiness, the importance of polyculture for family agriculture, among other aspects.

The other book of our study, the LDH 2 Vontade de Saber História - 6th grade, is also rich in images, photographs, drawings, maps. The identification of some paintings and photographs is done by the use of subtitles, as is the case of the images that appear in the introduction of the chapters, following the section "Talking about it". The figure presented below demonstrates how the picture-proof is used in order to prove the veracity of the narratives that are developed around the contents. However, it is important to stress that, "Although they are not only illustrations, once the images prove the data transmitted by the text and complement their ideas, there is not a keeper work of analysis of them" (Ströher, 2012, p. 56).

Figure 10 - Proof-image - LDH 2.

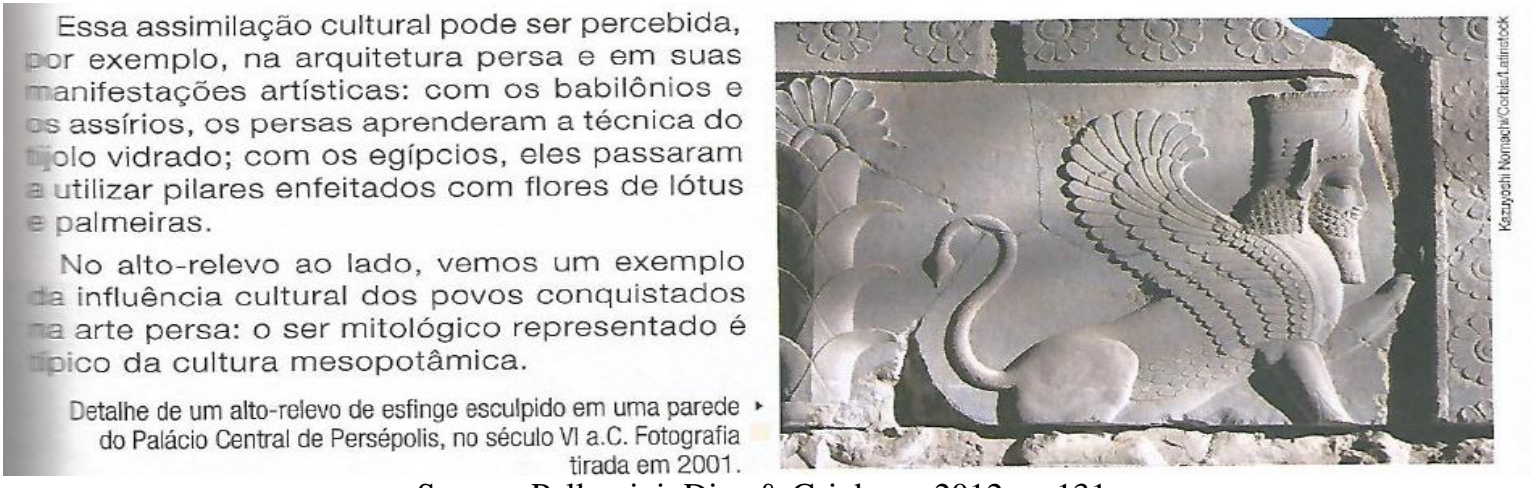

Source: Pellegrini, Dias \& Grinberg, 2012, p. 131.

The use of the images is quite used in the LDH 2. However, most of the images seem to be merely illustrative, without the intention to elucidate or instigate debate in the classroom, as shown in Figure 10. For Ströher (2012, p. 47), "Despite the good visual treatment of the images, it is important to stress that the role that these occupy in relation to the texts that accompany it is, often, the one of mere illustrations, or as of evidence that supports and confirm the written information". Often the work does not offer for the educator and the learner elements which enable problematize the proper reading of the images in order to deepen the discussion of the texts.

Still in the LDH 2, it is frequent the use of the images in the section "Activities", but not for the purpose of producing a dense interpretation of them, because what is usually proposed with the 
use of them is the observation, questions about the content, questions to compare them and describe the differences among them.

As regards the category imageillustration (Ströher, 2012), the
Iconographies below present in detail the type of image-illustration commonly used in the $\mathrm{LDH} 2$, when approached in an activity accompanying the content:

Figure 11 - Image-illustration - LDH 2.

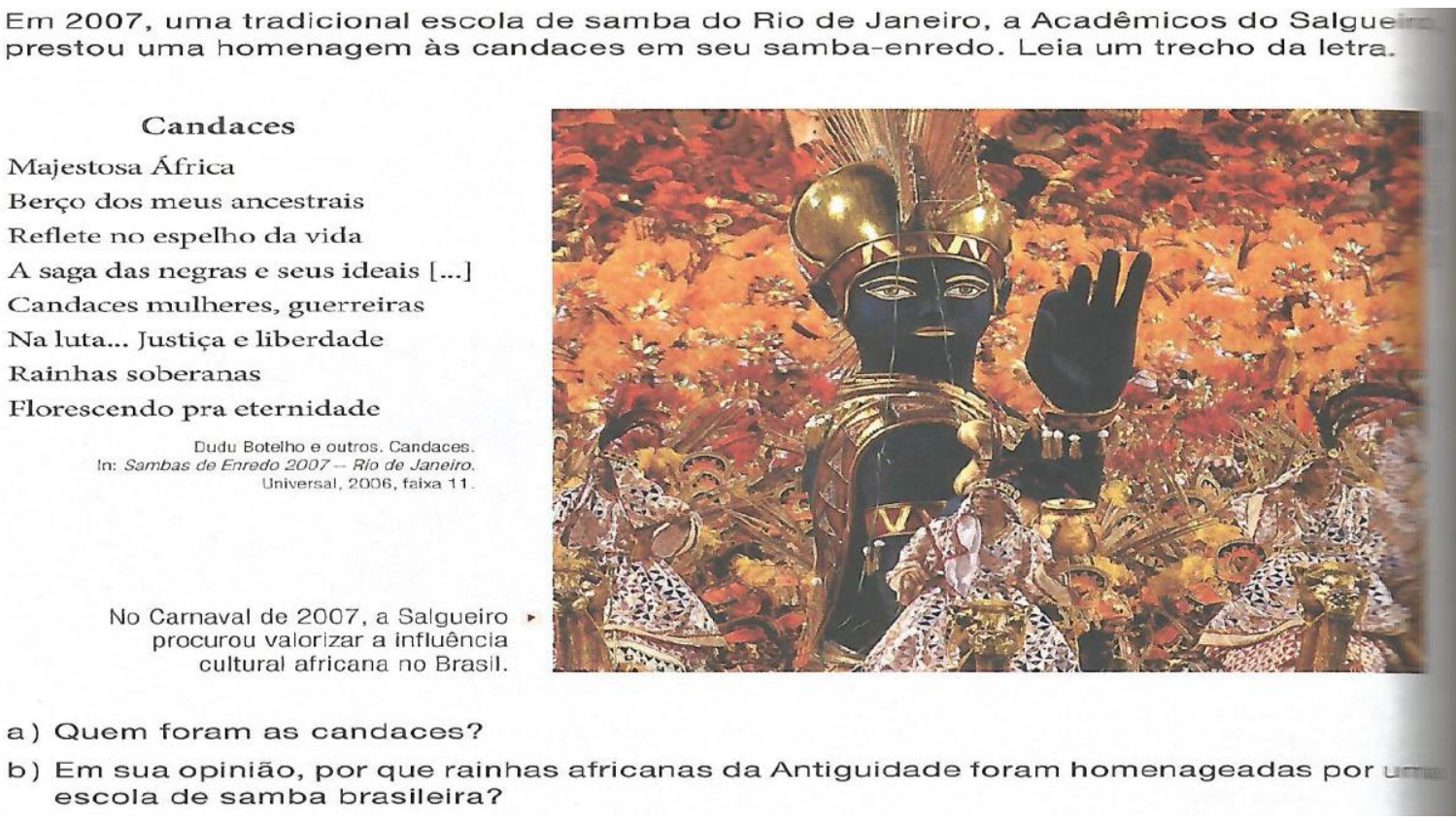

Source: Pellegrini, Dias \& Grinberg, 2012, p. 90.

According to Ströher (2012), there may be resizing of the images to prove the ideological conceptions that the texts present. The way how certain authors stand on the content demonstrates their current of thought. A phrase, a concept, a photo, a painting, a charge and a map, can be used "tendentiously" in order to reinforce a thought or a bigot idea, depending on how it will be worked the interpretation by the author.
Figure 12, presented below, shows a group of bushmen in the northeast of the years of 1940. This image depicts the hardships of life in the backwoods, the hard work to remove water from the well, the barefooted woman with a pot of water on the head, leaving explicit the difficulty of living in the northeastern backwoods: 
Figure 12 - Image-illustration - LDH 2.

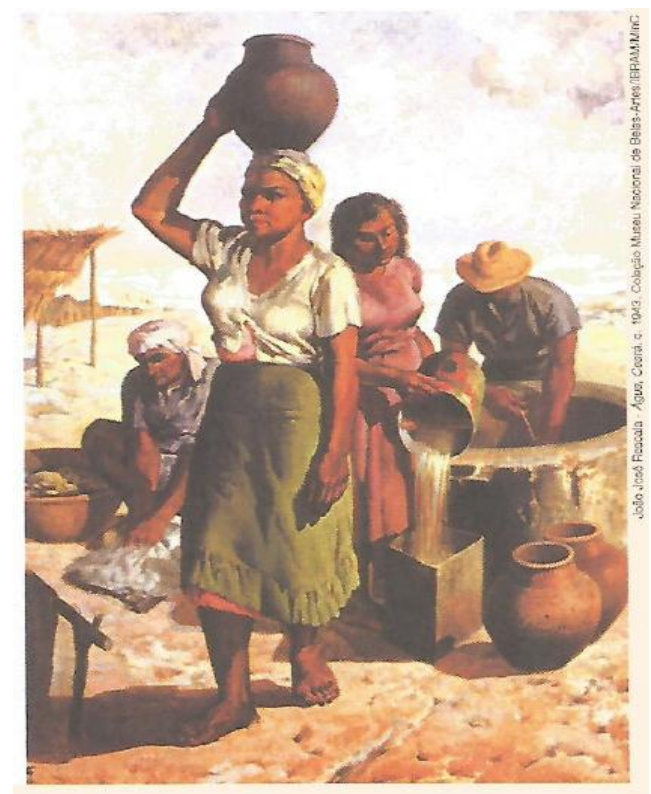

Source: Pellegrini, Dias \& Grinberg, 2012, p. 21.

Analyzing how the Figure 12 appears in the LDH 2, it is noted that there is no text to explain why these people depicted in the image are living in this situation. It is therefore an attempt to corroborate or legitimize the view that the countryside is suffering, even if it is not the intention of the author.

\section{Conclusion}

The school, the textbooks and the curriculum of the Rural Education, as advocated by the social movements of the countryside, it must work the pedagogy of the social movement, the peasant culture, the identity of the peasants. For this reason, we analyze in this article two textbooks of
History of 6th grade of Elementary School, taking into account the following elements: contents, activities, teacher-student interaction and pictures.

The LDH 1, Caderno de Ensino Aprendizagem: História 5, has its graphic project designed for the schools multigraded of the countryside. It is a teaching material whose base texts to comment regarding certain subject are reduced, since it explores as the methodological resources the innumerous exercises, that can be done through activities in couple or in collectiveness (through the exercises and some images the countryside is approached in the book). The work meets, even if partially, the longing of the movements of social 
struggles of the countryside (landless, bordering, quilombolas, affected people, extractive), because some themes of this book let you work the culture, the identity and the peasant struggle. However, we know that in some cases the LD is the only teaching material of the teacher who teaches in rural areas.

On the other hand, the LDH 2, Vontade de Saber História, it is a book prepared for an urban school, to form holder subjects of an instrumental knowledge and technical. The contents of this LD and their activities do not instigate the student to question the current reality, filled by the social inequities, because the book promotes the memorization of the concepts, dates and facts of the past. Therefore, the LDH 2, when used as a teaching tool in schools in the countryside, especially in those schools near the town, do not present theoretical and methodological subsidies that favor strengthening of the peasant identity, the struggle of the working class, the agrarian reform, the deconstruction of stereotypes. As we know, the scientific knowledge is not neutral, but must dialogue with the multiple contradictions experienced by the people in the countryside, that seek new ways to overcome the social injustices created by the capitalist system.
The research also reinforces that the success of the teaching materials in the classroom, regardless of the social context of the school and the community, it also depends on the teacher and the teaching methodology implemented, including specific aimed objectives and teaching vision about the process teaching and learning.

With these lines, we realize that the defense of the social movements by a Rural Education comes with a school that is of and in the countryside, in which the challenge is even greater: "When is discussed what to teach in those schools?"; "How to organize a curriculum that respects the cultural diversity?"; "How to elaborate textbooks respecting the various rural contexts that exist in Brazil?"”.

\section{References}

Arboit, A. A., \& Pacheco, L. M. D. (2013). Exclusão social no mundo rural: ideologia e poder nos livros didáticos. Vivências: Revista Eletrônica de Extensão da URI, 9(16), 140-152.

Arroyo, M. G. (2011). A Educação Básica e o Movimento Social do Campo. In Arroyo, M. G., Caldart, R. S., \& Molina, M. C. (Orgs.). Por uma educação do campo (pp. 08-86). Petrópolis, RJ: Vozes.

Arroyo, M. G. (2013). Currículo, território em disputa. Petrópolis, RJ: Vozes. 
Berbat, M., \& Feijó, G. (2016). Diálogos com a Educação do Campo: o livro didático em questão. Revista Brasileira de Educação do Campo, 1(2), 476-494. DOI: https://doi.org/10.20873/uft.2525$\underline{4863.2016 \mathrm{v} 1 \mathrm{n} 2 \mathrm{p} 476}$

Bogdan, R. C., \& Biklen, S. K. (1994). Investigação qualitativa em educação: uma introdução à teoria e aos métodos. Porto: Porto Editora.

Brasil. (2010). Escola Ativa: Projeto base. Brasília, DF: MEC/SECAD.

Brasil. (2012). Guia de livros didáticos: PNLD Campo 2013 - ensino fundamental. Brasília, DF: MEC/SECADI.

Brasil. (2013). Guia de livros didáticos: PNLD 2014 - história: ensino fundamental: anos finais. Brasília, DF: MEC/SEB.

Caldart, R. S. (2000). A escola do campo em movimento. In Benjamin, C., \& Caldart, R. S. (Orgs.). Projeto Popular e escolas do campo (pp. 24-48). Brasília, DF: Articulação Nacional Por uma Educação Básica do Campo.

Carie, N. S. (2008). Avaliações de Coleções Didáticas de História de $5^{a}$ a $8^{a}$ Série do Ensino Fundamental: um contraste entre os critérios avaliativos dos professores e do Programa Nacional do Livro Didático. (Dissertação de Mestrado). Universidade Federal de Minas Gerais, Belo Horizonte.

Costa, P. F. S. (2014). Análise do discurso dos livros didáticos para a Educação do Campo: aspectos semiolinguísticos da contextualização. (Dissertação de Mestrado). Universidade Federal de Minas Gerais, Belo Horizonte.

Filgueiras, J. M. (2013). A produção de materiais didáticos pelo MEC: da
Campanha Nacional de Material de Ensino à Fundação Nacional de Material Escolar. Revista Brasileira de História, 33(65), 313-335.

Freitas, N. K., \& Rodrigues, M. H. (2008). O Livro Didático ao longo do tempo: a forma do conteúdo. Pesquisa, 3, 26-33.

Pellegrini, M., Dias, A., \& Grinberg, K. (2012). Vontade de Saber História - $6^{\circ}$ ano. São Paulo, SP: FTD.

Silva, C. (2011). Pedagogia da Alternância: um estudo do gênero Caderno da Realidade com foco na retextualização. (Dissertação de Mestrado). Universidade Federal do Tocantins, Tocantins.

Silva, L. Q. (2010). Caderno de Ensino e Aprendizagem: História 5. Brasília, DF: MEC/SECAD.

Silva, W. R., et al. (2014). O que são materiais didáticos? Uma abordagem na Linguística Aplicada. In SILVA, W. R., Santos, J. S., \& Melo, M. A. (Orgs.). Pesquisas em Lingua(gem) e demandas do ensino básico (pp. 263-293). Campinas, SP: Pontes Editores.

Ströher, C. E. (2012). Aprendendo com imagens: a função das fontes visuais nos livros didáticos de História. Aedos, 11(4), 46-70.

\footnotetext{
${ }^{\mathrm{i}}$ We thank two anonymous reviewers of RBEC for the contributions to the work.

ii Conflicts of interest: Cicero da Silva is a member of the National Editorial Board of the Revista Brasileira de Educação do Campo, however, it did not have any participation in the evaluation process of the manuscript.

iii This research is part of the scientific activities of the Group for studies and research in Rural Education - Gepec (UFT/CNPq).
} 
iv We understanding the teaching material (MD), according to Silva et al. (2014, p. 264), as: “... embedded artifacts to the work of the teacher, serving as an aid to the teaching and learning process in training contexts".

v The Programa Escola Ativa (Active School Program) was deployed in Brazil in 1997, through the Northeast Project of the Ministry of education with the World Bank, being adopted by the School building Fund FNDE/FUNDESCOLA (Brasil, 2010). The Secretariat of Continuing Education, literacy and diversity (SECAD) is responsible for the program management. Brazil adopted this program having as model the experiment of Colombia, country in which the Escola Ativa was launched in 1975 (from 1986, the program receives funding from the World Bank to expand) (Melo \& Souza, 2013). Of the 5,565 municipalities in Brazil, 3,106 joined to the program in 2008. The Escola Ativa is intended for multigraded classes, or small schools, in places of difficult access and with low population density, with only one teacher. Students are organized together in the same classroom and must work in groups, facilitating the flow of information, which will be shared by other grades (Brasil, 2010).

vi As the "reading" involves directly the development of many activities linked to excerpts from historical, journalistic and literary texts throughout the chapters of the LDH 1 we do not need the total number of activities of the modality "reading" in this work.

Received August 22, 2017 Accepted September 15, 2017 Published December 15, 2017

\section{ORCID}

Cícero da Silva

(iD) http://orcid.org/0000-0001-6071-6711

Ilário Dias Cardoso Filho

(iD) http://orcid.org/0000-0003-3972-3698

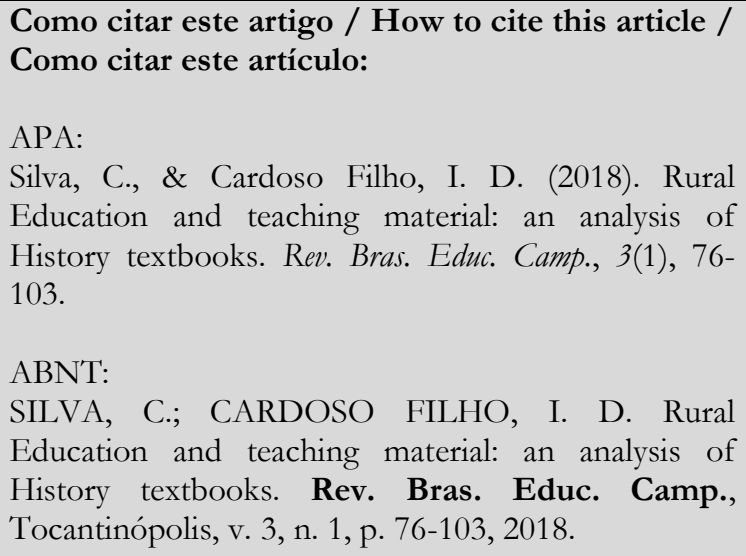
History textbooks. Rev. Bras. Educ. Camp., 3(1), 76103.

ABNT:

SILVA, C.; CARDOSO FILHO, I. D. Rural Education and teaching material: an analysis of History textbooks. Rev. Bras. Educ. Camp., Tocantinópolis, v. 3, n. 1, p. 76-103, 2018. 